\title{
Effects of Co-inoculation with Pratylenchus thornei and Fusarium culmorum on Growth and Yield of Winter Wheat
}

\author{
Abolfazl Hajihassani, Young Researchers and Elite Club, Arak Branch, Islamic Azad University, Arak, Iran; Richard W. Smiley, \\ Columbia Basin Agricultural Research Center, Oregon State University, Pendleton 97801; and Farahnaz Jahanshahi Afshar, \\ Department of Nematology, Iranian Research Institute of Plant Protection, Tehran, Iran
}

\begin{abstract}
Hajihassani, A., Smiley, R. W., and Afshar, F. J. 2013. Effects of co-inoculation with Pratylenchus thornei and Fusarium culmorum on growth and yield of winter wheat. Plant Dis. 97:1470-1477.

Growth and yield of winter wheat are suppressed by Pratylenchus thornei and by Fusarium culmorum. Many fields in cereal production regions throughout the world are infested by both pathogens. We evaluated effects of one or both pathogens on winter wheat growth, grain yield, and disease parameters at heading and harvest stages over 2 years in inoculated, rainfed pots incubated outdoors. $P$. thornei nematodes were inoculated at 1,2 , or 4 nematodes/g of soil and $F$. culmorum was added as colonized millet seed at $0.65 \mathrm{~g} / \mathrm{kg}$ of soil. At harvest, compared with the noninoculated control, the high rate of $P$. thornei reduced $(P<0.05)$ plant height, shoot weight, root weight, and grain

yield by $19,17,48$, and $31 \%$, respectively. F. culmorum alone reduced these parameters by $15,16,22$, and $22 \%$, respectively. Co-inoculations caused reductions of $27,38,61$, and $63 \%$, respectively. The reproductive rate of $P$. thorne $i$ was not greatly affected by co-inoculation with $F$. culmorum. Disease severity ratings at both plant growth stages became amplified as the nematode density was increased, and were much greater in the presence of both pathogens. Effects of co-inoculation on grain yield were slightly greater than predicted by additive effects of the individual pathogens, suggesting a synergistic effect on yield depression.
\end{abstract}

Production of cereals is constrained globally by root diseases caused by plant-parasitic nematodes and plant-pathogenic fungi. Nematodes most commonly associated with economic damage to wheat (Triticum aestivum L.), barley (Hordeum vulgare L.), and oat (Avena sativa L.) include the root-lesion nematodes Pratylenchus neglectus (Rench) Filipjev Schuurmanns \& Stekhoven and $P$. thornei Sher \& Allen, and the cereal cyst nematodes Heterodera avenae Woll., H. filipjevi Madzhidov, and H. latipons Franklin $(35,43)$. Likewise, essentially all temperate cereal-production regions are infested by pathogens causing root diseases such as Fusarium crown rot (Fusarium culmorum (W.G. Sm.) Sacc. and F. pseudograminearum O'Donnell \& T. Aoki), common root rot (Bipolaris sorokiniana (Sacc.) Shoemaker), Rhizoctonia root rot (Rhizoctonia solani J.G. Kühn AG-8), Pythium root rot (multiple species of Pythium Pringsheim), and take-all (Gaeumannomyces graminis var. tritici J. Walker) (39). The international literature is expansive for cereal diseases caused by these nematodes and fungi. However, most reports are focused upon the biology and management of a single causal agent. Reports of associations between species of nematodes, species of fungi, or of nematodes and fungi are much less common.

Interactions between root-invading nematodes and root-infecting fungi have been known for more than a century (2). However, most reviews and individual reports have addressed interactions of nematodes with vascular wilt fungi such as Verticillium dahliae and $F$. oxysporum $(1,3,7,10,22,32,34,49,52)$. Vascular wilt diseases are uncommon in cereals, being limited to Cephalosporium stripe (Cephalosporium gramineum), which occurs in only a small number of cool-temperature wheat-producing regions (39). There have been few studies of interactions of nematodes with root-rotting fungi on cereals $(5,23,24,37,45)$.

Corresponding author: A. Hajihassani,

E-mail: hajihasa@cc.umanitoba.ca and abolfazl_hajihasani@yahoo.com

Accepted for publication 1 May 2013.

http://dx.doi.org/10.1094/PDIS-02-13-0168-RE

(C) 2013 The American Phytopathological Society
Benedict and Mountain (5) reported that $P$. neglectus was closely associated with Rhizoctonia root rot of wheat, and that the nematode appeared to initiate the occurrence of disease caused by the fungal pathogen. Taheri et al. (45) also described complex interactions between $P$. neglectus and a broad range of root-infecting fungal pathogens on wheat. They determined that numbers of nematodes and severity of root lesions were typically greater on roots that were co-infected than on roots infected with only one of these pathogens. They also found that fungal pathogens may cause greater damage in roots initially wounded by the nematode. Rhizoctonia root rot and take-all each increased reproduction of $P$. neglectus in roots, and reproduction of the nematode was suppressed when $R$. solani and G. graminis were both present.

Wheat fields in Iran are commonly infested by nematodes such as $H$. avenae, $H$. filipjevi, $H$. latipons, $P$. neglectus, $P$. thornei, and Scutylenchus brevidens $(13,17,47,48)$, and by fungi such as $F$. culmorum, $F$. pseudograminearum, $R$. cerealis, or $B$. sorokiniana $(11,12,14,16,19,20,33,36,47,53)$. Tanha Maafi (46) indicated that $P$. thornei and $P$. neglectus were the most common species of plantparasitic nematodes detected on cereals (wheat, barley, and corn) in Iran. During another survey of wheat fields in six major wheatproducing provinces of Iran, Tanha Maafi et al. (47) reported that Heterodera and Pratylenchus spp. were each detected in more than half the soil or root samples collected, and that $F$. culmorum and $F$. pseudograminearum were isolated from 13 and $11 \%$ of plants sampled, respectively. Hajihasani et al. (12) also determined that as much as $17 \%$ of wheat seed in Markazi Province was contaminated by spores of $F$. culmorum. Fusarium spp. are often found in combination with species of Pratylenchus or Heterodera in infested soils and in infected plants (47). Recent research in Australia revealed that, when fields were co-infested with $P$. thornei and $F$. pseudograminearum, bread wheat cultivars having the least tolerance to the nematode expressed the greatest yield loss from the fungal pathogen even when environmental conditions were not particularly conducive to crown rot development (38). Pratylenchus spp. reduce the ability of wheat plants to extract water and nutrients from the soil profile $(21,42,50,51)$. Severity of Fusarium crown rot increases with an increasing level of plant water stress, particularly late in the growing season $(6,8,28)$. It is likely that crown rot (F. pseudograminearum) in Australia became exacer- 
bated as $P$. thornei enhanced plant stress by limiting the acquisition or transport of water and nutrients to the foliage.

The objective of this research was to investigate the influence of co-inoculations of $P$. thornei and $F$. culmorum under simulated field conditions on growth and yield of winter wheat.

\section{Materials and Methods}

Two experiments were carried out under field conditions during 2010-11 and 2011-12 at the Agriculture Research Center, Markazi Province, Arak, Iran (latitude $34^{\circ} 06^{\prime} \mathrm{N}$, longitude $49^{\circ} 46^{\prime} \mathrm{E}$, altitude $1,720 \mathrm{~m}$ ). Mean annual precipitation at Arak is $272 \mathrm{~mm}$, with a fluctuating annual range of 200 to $400 \mathrm{~mm}$. Winters are cold, with mean monthly temperature of $<2.0^{\circ} \mathrm{C}$ from December through February. Summers are warm to hot, with mean monthly high temperature exceeding $30^{\circ} \mathrm{C}$ from June through September.

The experiments were performed using terracotta pots. Each pot had a small hole in the bottom and contained $2 \mathrm{~kg}$ of steam-pasteurized clay loam soil collected from the field. Soil consisted of sand, silt, and clay at 38,32, and 30\%, respectively, and a $\mathrm{pH}$ of 7.3. During early November each year, seed of winter wheat 'Sardari' were surface disinfested with $1.5 \%$ sodium hypochlorite solution for $2 \mathrm{~min}$, rinsed in sterile water and placed on a plate containing two layers of moist Whatman filter paper. The plates were incubated in a growth chamber at $25^{\circ} \mathrm{C}$. When coleoptiles were 1 $\mathrm{cm}$ long, two seedlings were transplanted at a $2-\mathrm{cm}$ depth into soil in each pot.

Inocula. $P$. thornei was extracted from roots of wheat collected in 2008 from a wheat field with a history of infection in Kermanshah Province of western Iran. The species was identified using morphological characteristics (18). Extracted nematodes were surface disinfested by suspension in streptomycin sulfate at 4,000 $\mu \mathrm{g} / \mathrm{g}(1 \%)$ for $24 \mathrm{~h}$ and rinsing three times in sterile distilled water. Pure cultures were established by placing 15 to 20 surface-sterilized $P$. thornei nematodes onto sterilized carrot discs (25) that were maintained in an incubator at $23^{\circ} \mathrm{C}$. The nematodes were extracted from carrot disks using the Whitehead and Hemming tray

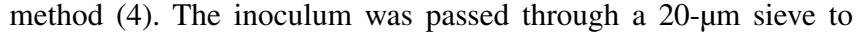
obtain a uniform population of the nematode by separating eggs from juveniles. The nematode density was determined from 1-ml aliquots and appropriate dilutions were prepared for dispensing 1, 2 , or 4 juveniles/g of soil $(P i)$ in $10 \mathrm{ml}$ of suspension, which was placed into the soil around each seedling at the time of transplanting.

F. culmorum was isolated from field soil collected near Shazand (Markazi Province), where the pathogen commonly causes disease of barley (31) and wheat (unpublished data). Cultures were identified using morphological characteristics (26). Single-spore cultures were subcultured onto plates of potato-dextrose agar (PDA) medium and incubated at $25^{\circ} \mathrm{C}$ until fungal growth covered the 90 $\mathrm{mm}$-diameter plates. Millet seed inoculum was produced in $500-\mathrm{ml}$ Erlenmeyer flasks containing $250 \mathrm{~g}$ of twice-autoclaved millet seed and three plugs of fungal medium (40). Flasks were incubated at $26 \pm 2{ }^{\circ} \mathrm{C}$ for 3 to 4 weeks and shaken every other day to optimize fungal growth. The uniformly colonized seed were air dried, sieved to eliminate clumps, and stored at room temperature in paper bags. Soil was infested at a rate of $1.3 \mathrm{~g}$ of millet per pot (millet at 0.65 $\mathrm{g} / \mathrm{kg}$ of soil) by placing the colonized seed on the surface of the soil above the wheat seed.

Treatments. Pots were buried into soil in an outdoor nursery, leaving $5 \mathrm{~cm}$ of pot remaining above the soil surface. The experimental design was a randomized complete block with nine replications of the following eight treatments: (i) control (wheat plant uninoculated by pathogens); (ii) $P$. thornei alone, 1 juvenile/g of soil; (ii) P. thornei alone, 2 juveniles/g of soil; (iv) $P$. thornei alone, 4 juveniles/g of soil; (v) $F$. culmorum alone, colonized millet seed at $0.65 \mathrm{~g} / \mathrm{kg}$ of soil; (vi) P. thornei (1 juvenile/g of soil) $+F$. culmorum $(0.65 \mathrm{~g} / \mathrm{kg})$, inoculated simultaneously; (vii) P. thornei (2 juveniles $/ \mathrm{g}$ of soil $)+F$. culmorum $(0.65 \mathrm{~g} / \mathrm{kg})$, inoculated simultaneously; and (viii) P. thornei (4 juveniles/g of soil) $+F$. culmorum $(0.65 \mathrm{~g} / \mathrm{kg})$, inoculated simultaneously.
Plants were grown under rainfed conditions and received supplemental water only at the time of inoculation. Plants were fertilized twice with $250 \mathrm{ml}$ of water-soluble NPK (20:20:20, $0.5 \% \mathrm{vol} / \mathrm{vol}$ ) fertilizer in late November and in mid-April each growing season.

Sampling. Monthly precipitation in Arak during the experiment was acquired from historical records at http://www.markazimet.ir/ english/index.htm. Data on the growth parameters were recorded at two plant growth stages each year. Before heading (Feekes growth stage 10), plants in four replicates per treatment were assessed for plant height (in centimeters), shoot dry weight (in grams), and root dry weight (in grams). At harvest, plants in the remaining five replicates were assessed for plant height (in centimeters), shoot dry weight (in grams), root dry weight (in grams), grain yield (in grams per pot), and final nematode density $(P f)$. Plant shoots were cut from the soil surface in each pot and the shoot and root systems were each oven dried $\left(70^{\circ} \mathrm{C}\right.$ for $\left.24 \mathrm{~h}\right)$ and weighed.

The reproductive factor of $P$. thornei was determined by dividing $P f$ by $P i$. The $P f$ was determined from the total number of freeliving nematode stages extracted from soil and roots of each pot. After soil was removed from each pot and thoroughly mixed, a 150-ml subsample from each pot was used to extract juveniles using the Whitehead tray method. The average nematode density in the subsample was determined in three 1-ml aliquots of suspension under a compound microscope. To account for all nematodes in the soil plus roots, the root systems in each pot were also washed free of soil and the nematodes in roots were extracted by randomly cutting 1-g subsamples of roots using the method described by Coolen and D'Herde (9).

Symptoms of root-lesion nematode damage are generally inconspicuous and are not diagnostic $(7,43,46)$. Rating systems for severity of Fusarium crown rot vary considerably. For field-grown plants, most systems visually assess the extent of browning of basal internodes on the culm or of the percentage of culms which die prematurely, as measured by development of "whiteheads" containing shriveled kernels of grain $(6,28,39)$. For controlled-environment studies, most systems visually assess the extent of browning on lower leaf sheaths, as summarized by Poole et al. (30). Because effects of $P$. thornei and $F$. culmorum cannot be reliably rated independently for adult-plant studies performed outdoors, we used the following descriptive rating scale that combined effects of both pathogens but was most similar to rating scales used to assess effects of crown rot. Ratings were performed each year before heading and at harvest using a 1-to-5 scale, where $1=$ weak browning and lesion development on the scutellar node; $2=$ severe browning and lesion development on the scutellar node; 3 = browning of scutellar node and either the subcrown internode or leaf sheath; $4=$ living plant with browning of scutellar node, subcrown internode, and leaf sheaths; and $5=$ dying plant with rotted culm and stem base.

Analysis of data. Analyses of variance (ANOVA) were performed using SAS Proc GLM (SAS Institute). A one-way randomized block analysis was used to determine differences among eight treatments for each measured parameter during each year. When treatment differences were significant at $P<0.05$, the Tukey's honestly significant difference test was used to determine mean differences among treatments. A three-way randomized block analysis was used to determine main effects of year and pathogen (none, P. thornei, or F. culmorum) and of their interaction. Because the main effect of year was typically significant but of minimal numerical difference, and the year-treatment interactions were consistently significant only for disease severity, the effect of year was considered to be of minimal biological importance. Therefore, data were grouped over years and evaluated by regression analysis using a quadratic model. Two regressions were performed: (i) for P. thornei alone at nil, 1, 2, and 4 nematodes/g of soil or (ii) those four treatments with co-inoculation of $F$. culmorum. The $F$. culmorum-alone treatment was included in the second grouping as the $F$. culmorum treatment at the "zero" rate of inoculation by $P$. thornei. Percentage reduction of each datum point on each regression 
as compared with soil not inoculated with either pathogen was also determined using all data measured over the 2 years of this study.

\section{Results}

Precipitation. Rain plus snow during the 2011 crop year (Fig. 1) was $22 \%$ less than the mean annual average of $272 \mathrm{~mm} ; 212$ mm occurred during the experimental period from 1 November 2010 to 30 July 2011. Precipitation occurred during each of the first 7 months of the experiment. During the 2012 crop year, the precipitation $(265 \mathrm{~mm})$ was near the long-term average for the area but $79 \%$ of the total precipitation for the first 7 months occurred during 2 months; November and April (Fig. 1). During both years, no effective precipitation occurred during the 2-month period before wheat was harvested.

Plant growth and disease parameters. Inoculation of soil with either $P$. thornei or $F$. culmorum reduced $(P<0.01)$ plant height, shoot dry weight, and root dry weight recorded at the heading and harvest sampling periods during both years (Table 1). Each pathogen individually also reduced grain yield each year. Plant growth

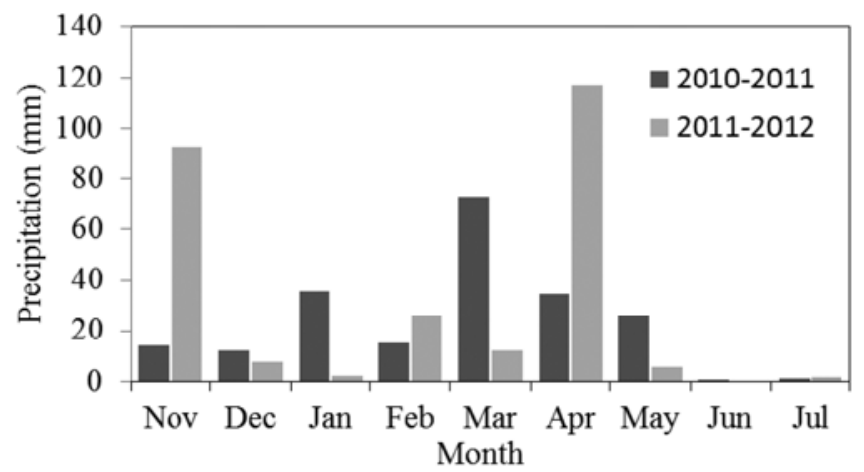

Fig. 1. Distribution of precipitation at Arak, Iran during 9 months of experimentation from November through July 2010-11 and 2011-12. and yield were nearly always lower when grown under the influence of both pathogens as compared with only one of the pathogens.

Disease severity ratings for plants in pots inoculated with $P$. thornei alone were greater than for the noninoculated control during both years. Disease severity ratings were greater in plants inoculated with $F$. culmorum alone than for the control during the second year but not during the first year (Table 1). Disease severity ratings were nearly always higher in pots inoculated with both pathogens compared with either pathogen alone.

When data were grouped over years, the main effect for each pathogen was always highly significant $(P<0.0001)$ for each plant growth and yield parameter and for disease severity and the nematode reproductive factor (Table 2). The main effect for year was highly significant for seven of the nine parameters measured but the actual differences were generally small: $4 \%$ or less for each of the plant growth parameters and for grain yield. Differences in disease severity ratings were higher, $6 \%$ at heading stage and $14 \%$ at harvest; but, again, the differences of only 0.1 rating unit at heading time and 0.3 unit at harvest were considered to be of minimal importance on the 0-to-5 scale used. Therefore, data were grouped over years for further evaluation because we concluded that the main effect of year was unimportant.

Interactions among main effects were also common, particularly for the interaction between $P$. thornei and F. culmorum. However, the nature of these interactions was not readily identifiable and they were not considered further. With few exceptions, the yearpathogen interactions were not significant (Table 2). Exceptions included the interaction for root dry weight at the heading stage and disease severity at heading for F. culmorum and for both pathogens at harvest. At the heading stage, an increasing density of $P$. thornei led to a more rapid decline in root dry weight during the year of more normally distributed precipitation (2010-11) than during the year with only two wet months (2011-12). Disease severity ratings increased as the $P$. thornei inoculum density increased during both years but the maximum ratings were greater

Table 1. Plant growth, grain yield, disease severity ratings, and nematode reproductive factor for rainfed winter wheat over two seasons when grown in pots incubated under field conditions and inoculated with Pratylenchus thornei $(\mathrm{Pt})$ at initial densities of 1 , 2, or 4 juveniles/g of soil (Pt1, Pt2, and Pt4), with Fusarium culmorum $(\mathrm{Fc})$ colonized millet seed at a rate of $0.65 \mathrm{~g} / \mathrm{kg}$ of soil, or co-inoculations with $P$. thornei and F. culmorum $^{\mathrm{w}}$

\begin{tabular}{|c|c|c|c|c|c|c|c|c|c|c|c|}
\hline \multirow[b]{2}{*}{ Treatment $^{\mathrm{z}}$} & \multicolumn{2}{|c|}{$\begin{array}{l}\text { Plant height } \\
(\mathrm{cm})\end{array}$} & \multicolumn{2}{|c|}{$\begin{array}{c}\text { Shoot dry weight } \\
\text { (g) }\end{array}$} & \multicolumn{2}{|c|}{$\begin{array}{l}\text { Root dry weight } \\
\text { (g) }\end{array}$} & \multicolumn{2}{|c|}{$\begin{array}{l}\text { Disease severity } \\
\text { rating }(0 \text { to } 5)^{\mathrm{x}}\end{array}$} & \multicolumn{2}{|c|}{$\begin{array}{c}\text { Grain yield/pot } \\
\text { (g) }\end{array}$} & \multirow{2}{*}{$\begin{array}{c}\begin{array}{c}\text { Nematode } \\
\text { Rf }^{\mathbf{y}}\end{array} \\
2011-12 \\
\end{array}$} \\
\hline & 2010-11 & 2011-12 & 2010-11 & 2011-12 & 2010-11 & 2011-12 & 2010-11 & 2011-12 & 2010-11 & 2011-12 & \\
\hline \multicolumn{12}{|l|}{ Heading } \\
\hline Control & $49.6 \mathrm{a}$ & $48.4 \mathrm{a}$ & $13.4 \mathrm{a}$ & $12.5 \mathrm{a}$ & $3.7 \mathrm{a}$ & $3.6 \mathrm{a}$ & $0.0 \mathrm{f}$ & $0.0 \mathrm{e}$ & $\ldots$ & $\ldots$ & $\ldots$ \\
\hline Pt1 & $44.9 \mathrm{~b}$ & $42.9 \mathrm{~b}$ & $11.1 \mathrm{~b}$ & $10.6 \mathrm{~b}$ & $2.9 \mathrm{~b}$ & $3.2 \mathrm{~b}$ & $1.2 \mathrm{e}$ & $1.2 \mathrm{~d}$ & $\ldots$ & $\ldots$ & $\ldots$ \\
\hline Pt2 & $41.9 \mathrm{c}$ & $41.0 \mathrm{~b}$ & $9.8 \mathrm{c}$ & $9.6 \mathrm{bc}$ & $2.7 \mathrm{~b}$ & $2.9 \mathrm{bc}$ & $1.4 \mathrm{e}$ & $1.5 \mathrm{~d}$ & $\ldots$ & $\ldots$ & $\ldots$ \\
\hline $\mathrm{Pt} 4$ & $38.8 \mathrm{~d}$ & $37.1 \mathrm{~cd}$ & $7.9 \mathrm{~d}$ & $8.4 \mathrm{~cd}$ & $2.0 \mathrm{~cd}$ & $2.5 \mathrm{~cd}$ & $2.1 \mathrm{~cd}$ & $2.1 \mathrm{c}$ & $\ldots$ & $\ldots$ & $\ldots$ \\
\hline $\mathrm{Fc}$ & $43.3 \mathrm{bc}$ & $41.3 \mathrm{~b}$ & $9.2 \mathrm{c}$ & $8.8 \mathrm{~cd}$ & $2.7 \mathrm{~b}$ & $2.7 \mathrm{~cd}$ & $2.0 \mathrm{~d}$ & $2.2 \mathrm{c}$ & $\ldots$ & $\ldots$ & $\ldots$ \\
\hline $\mathrm{Pt} 1+\mathrm{Fc}$ & $39.3 \mathrm{~d}$ & $40.2 \mathrm{bc}$ & $8.8 \mathrm{~cd}$ & $8.4 \mathrm{~cd}$ & $2.2 \mathrm{c}$ & $2.4 \mathrm{~d}$ & $2.3 \mathrm{c}$ & $2.6 \mathrm{~b}$ & $\ldots$ & $\ldots$ & $\ldots$ \\
\hline $\mathrm{Pt} 2+\mathrm{Fc}$ & $37.0 \mathrm{~d}$ & $36.6 \mathrm{~cd}$ & $7.7 \mathrm{~d}$ & $7.7 \mathrm{de}$ & $2.0 \mathrm{~cd}$ & $1.8 \mathrm{e}$ & $2.7 \mathrm{~b}$ & $3.0 \mathrm{ab}$ & $\ldots$ & $\ldots$ & $\ldots$ \\
\hline $\mathrm{Pt} 4+\mathrm{Fc}$ & $33.8 \mathrm{e}$ & $33.8 \mathrm{~d}$ & $6.6 \mathrm{e}$ & $6.5 \mathrm{e}$ & $1.6 \mathrm{~d}$ & $1.6 \mathrm{e}$ & $3.1 \mathrm{a}$ & $3.2 \mathrm{a}$ & $\ldots$ & $\ldots$ & $\ldots$ \\
\hline CV (\%) & 2.5 & 4.0 & 5.2 & 7.1 & 8.2 & 6.5 & 7.8 & 8.2 & $\ldots$ & $\ldots$ & $\ldots$ \\
\hline \multicolumn{12}{|l|}{ Harvest } \\
\hline Control & $64.1 \mathrm{a}$ & $62.7 \mathrm{a}$ & $22.2 \mathrm{a}$ & $21.8 \mathrm{a}$ & $3.9 \mathrm{a}$ & $3.6 \mathrm{a}$ & $0.0 \mathrm{e}$ & $0.0 \mathrm{~g}$ & $9.5 \mathrm{a}$ & $9.5 \mathrm{a}$ & \\
\hline Pt1 & $60.1 \mathrm{~b}$ & $58.2 \mathrm{~b}$ & $21.3 \mathrm{ab}$ & $20.0 \mathrm{~b}$ & $3.2 \mathrm{~b}$ & $3.1 \mathrm{~b}$ & $3.5 \mathrm{~b}$ & $1.3 \mathrm{f}$ & $8.5 \mathrm{~b}$ & $8.2 \mathrm{~b}$ & $3.4 \mathrm{~b}$ \\
\hline $\mathrm{Pt} 2$ & $57.2 \mathrm{c}$ & $55.4 \mathrm{bc}$ & $20.1 \mathrm{bc}$ & $19.3 \mathrm{bc}$ & $2.7 \mathrm{c}$ & $2.7 \mathrm{~b}$ & $3.0 \mathrm{c}$ & $1.6 \mathrm{ef}$ & $7.6 \mathrm{c}$ & $7.7 \mathrm{bc}$ & $3.1 \mathrm{bcd}$ \\
\hline Pt4 & $52.6 \mathrm{~d}$ & $50.6 \mathrm{~d}$ & $18.2 \mathrm{~d}$ & $18.1 \mathrm{c}$ & $1.9 \mathrm{~d}$ & $2.0 \mathrm{c}$ & $2.6 \mathrm{~d}$ & $2.1 \mathrm{~d}$ & $6.5 \mathrm{~d}$ & $6.5 \mathrm{de}$ & $2.8 \mathrm{~d}$ \\
\hline $\mathrm{Fc}$ & $54.8 \mathrm{~cd}$ & $53.0 \mathrm{~cd}$ & $18.7 \mathrm{~cd}$ & $18.4 \mathrm{c}$ & $3.0 \mathrm{bc}$ & $2.9 \mathrm{bc}$ & $0.0 \mathrm{e}$ & $1.8 \mathrm{de}$ & $7.6 \mathrm{c}$ & $7.1 \mathrm{~cd}$ & $\ldots$ \\
\hline $\mathrm{Pt} 1+\mathrm{Fc}$ & $54.4 \mathrm{~d}$ & $52.3 \mathrm{~d}$ & $18.5 \mathrm{~d}$ & $16.6 \mathrm{~d}$ & $1.9 \mathrm{~d}$ & $2.0 \mathrm{c}$ & $3.8 \mathrm{a}$ & $2.5 \mathrm{c}$ & $6.4 \mathrm{~d}$ & $6.0 \mathrm{e}$ & $3.8 \mathrm{a}$ \\
\hline $\mathrm{Pt} 2+\mathrm{Fc}$ & $49.4 \mathrm{e}$ & $47.3 \mathrm{e}$ & $15.4 \mathrm{e}$ & $15.0 \mathrm{e}$ & $1.7 \mathrm{de}$ & $1.6 \mathrm{~cd}$ & $3.1 \mathrm{c}$ & $2.9 \mathrm{~b}$ & $5.4 \mathrm{e}$ & $5.1 \mathrm{f}$ & $3.3 \mathrm{bc}$ \\
\hline $\mathrm{Pt} 4+\mathrm{Fc}$ & $47.3 \mathrm{e}$ & $44.7 \mathrm{e}$ & $13.8 \mathrm{f}$ & $13.3 \mathrm{f}$ & $1.5 \mathrm{e}$ & $1.5 \mathrm{~d}$ & $2.9 \mathrm{c}$ & $3.3 \mathrm{a}$ & $3.7 \mathrm{f}$ & $3.4 \mathrm{~g}$ & $3.0 \mathrm{~cd}$ \\
\hline CV (\%) & 2.5 & 2.8 & 4.0 & 3.4 & 6.6 & 10.2 & 5.7 & 7.4 & 5.9 & 6.1 & 5.1 \\
\hline
\end{tabular}

${ }^{\mathrm{w}}$ Data were collected at two plant growth stages: before heading and at the time of harvest. Means followed by the same letter within a column and within a plant growth stage do not differ significantly at $P<0.05$ according to the Tukey's honestly significant difference test. Means are of four plants (pots) at the heading stage and five plants (pots) at harvest.

${ }^{x}$ Disease severity scale: $0=$ none; $1=$ weak browning and lesions on the scutellar node; $2=$ severe browning and lesions on the scutellar node; $3=$ browning of scutellar node and either the subcrown internode or leaf sheath; 4 = living plant with browning of scutellar node, subcrown internode, and leaf sheaths; and $5=$ dying plant with rotted culm and stem base.

${ }^{y}$ Reproductive factor (Rf) is the final nematode density $(P f)$ divided by the initial inoculum density $(P i)$.

${ }^{\mathrm{z}}$ Growth stage and treatment; $\mathrm{CV}=$ coefficient of variation. 
during 2010-11 than during 2011-12 (Table 1). Inoculation with $F$. culmorum alone resulted in higher disease severity ratings at the heading stage during the year with highly irregular distribution of precipitation (2011-12) but did not differ from the control during the year with a more normal distribution of precipitation (201011). Co-inoculation of $P$. thornei with $F$. culmorum led to the highest disease severity rating at the lowest nematode density during 2010-11 and at the highest nematode density during 2011-12.

For data grouped over years, shoot weight, plant height, and root weight each decreased and disease severity ratings increased as the $P$. thornei nematode inoculum rate was increased from 0 to 4 nematodes/g of soil (Fig. 2). Compared with inoculation with the nematode alone, co-inoculation of pots with both $P$. thornei and $F$. culmorum resulted in further depressed plant growth parameters and increased disease severity. Grain yield also decreased as the nematode inoculum rate increased (Fig. 3) and, compared with inoculations of the nematode alone, the yield was further depressed in the presence of both pathogens. The 2-year percent reduction in plant growth and yield are shown in Table 3, and data for individual years are presented in Table 1 .

Depending upon the year, and compared with the noninoculated control treatment, the presence of both $F$. culmorum and $P$. thornei at the greatest nematode density tested resulted in reduced plant height, shoot weight, and root weight by as much as 31,49 , and $57 \%$, respectively, at the heading stage and by as much as 27,38 , and $61 \%$, respectively, at harvest (Table 3 ). Likewise, grain yield was reduced as much as $63 \%$ by co-inoculation. At harvest, with data averaged over 2 years and compared with the noninoculated control, the high rate of $P$. thornei resulted in reduced $(P<0.05)$ plant height, shoot weight, root weight, and grain yield by 19, 17, 48 , and $31 \%$, respectively. F. culmorum alone reduced these parameters by $15,16,22$, and $22 \%$, respectively. Co-inoculations caused additive reductions of 34, 33, 70, and 53\%, respectively. Effects of each individual pathogen and the combination of pathogens were more strongly expressed for root weight and grain yield than for shoot weight and plant height. Co-inoculation with both pathogens nearly always had a greater effect than either pathogen alone when compared at equal rates of inoculum with $P$. thornei (Table 1).

The reproductive factor for $P$. thornei during 2011/2012 decreased as the initial inoculum density was increased (Table 1; Fig.
3) and did not differ significantly when plants were also inoculated with F. culmorum.

\section{Discussion}

The primary objective of this research was to evaluate effects of co-inoculations of $P$. thornei and $F$. culmorum on growth and yield of winter wheat in an outdoor setting that simulated natural field conditions. This experiment differed from most previous experiments in that it was performed with inoculated soil influenced by the full range of naturally imposed stresses that could affect the outcome of plant diseases and their interactions.

As expected, when inoculated individually and compared with the noninoculated control, both pathogens reduced plant height, shoot weight, root weight, and grain yield. Likewise, disease severity increased with all inoculation treatments except the $F$. culmorum-alone treatment in the 2010-11 experiment. Compared with inoculations with each density of the nematode alone, disease severity became further elevated in the presence of both pathogens, and plant growth and grain yield were further depressed. The reproductive factor for $P$. thornei decreased as the initial inoculum density was increased and this was presumed to have been a response to the reduction in root biomass and competition for resources (noninvaded cortical cells) among individuals at the higher rates of inoculation.

The pathogens evaluated in this study invade different plant tissues and cause injury in very different ways. P. thornei feeds ectotrophically on root hairs and epidermal cells and invades and migrates through the root cortex $(7,43)$. Absorbance of water and nutrients are affected in the zone of nematode invasion but the vascular tissue remains intact and can supply water and nutrients to the shoot from roots distal to the zone where Pratylenchus nematodes have invaded the cortical and epidermal tissues. Because the nematode can occur deep within the soil profile, many or most wheat roots in infested soil are capable of being invaded. In contrast, F. culmorum primarily invades and causes a rotting of basal leaf and crown tissue $(6,39)$. It may also invade the subcrown internode and, occasionally, the roots. Therefore, disease caused by this fungal pathogen disrupts the continuity of water and nutrient transmission via the crown and basal stem and through the subcrown internode, which connects the seminal root system to all other plant tissues. Therefore, the locations at which these dry rots of

Table 2. Analyses of main effects of Pratylenchus thornei $(\mathrm{Pt})$, Fusarium culmorum $(\mathrm{Fc})$, year $(\mathrm{Yr})$, and of their interactions on growth parameters of rainfed winter wheat and disease severity and nematode reproductive factor (Rf) in pots incubated under field conditions ${ }^{\mathrm{x}}$

\begin{tabular}{|c|c|c|c|c|c|c|c|c|c|c|c|c|c|}
\hline \multirow[b]{2}{*}{ Variability $^{\mathbf{z}}$} & \multirow[b]{2}{*}{ df } & \multicolumn{2}{|c|}{ Plant height } & \multicolumn{2}{|c|}{ Shoot dry weight } & \multicolumn{2}{|c|}{ Root dry weight } & \multicolumn{2}{|c|}{ Disease severity } & \multicolumn{2}{|c|}{ Grain yield } & \multicolumn{2}{|c|}{$\mathbf{R f}^{\mathbf{y}}$} \\
\hline & & $\boldsymbol{F}$ & $P>F$ & $\boldsymbol{F}$ & $P>F$ & $\boldsymbol{F}$ & $P>F$ & $\boldsymbol{F}$ & $P>F$ & $\boldsymbol{F}$ & $P>F$ & $\boldsymbol{F}$ & $P>F$ \\
\hline \\
\hline \multicolumn{14}{|l|}{ Main effects } \\
\hline P. thornei & 3 & 138.43 & $<0.0001$ & 120.37 & $<0.0001$ & 136.59 & $<0.0001$ & 281.06 & $<0.0001$ & $\ldots$ & $\ldots$ & $\ldots$ & $\ldots$ \\
\hline F. culmorum & 1 & 195.78 & $<0.0001$ & 312.27 & $<0.0001$ & 327.10 & $<0.0001$ & $1,328.55$ & $<0.0001$ & $\ldots$ & $\ldots$ & $\ldots$ & $\ldots$ \\
\hline Year & 1 & 6.80 & 0.0123 & 3.19 & 0.0809 & 5.64 & 0.0218 & 9.43 & 0.0036 & $\ldots$ & $\ldots$ & $\ldots$ & $\ldots$ \\
\hline \multicolumn{14}{|l|}{ Interaction } \\
\hline $\mathrm{Pt} \times \mathrm{Fc}$ & 3 & 2.84 & 0.0482 & 13.23 & $<0.0001$ & 1.45 & 0.2414 & 28.04 & $<0.0001$ & $\ldots$ & $\ldots$ & $\ldots$ & $\ldots$ \\
\hline $\mathrm{Pt} \times \mathrm{Yr}$ & 3 & 0.44 & 0.7249 & 1.81 & 0.1585 & 3.73 & 0.0178 & 0.54 & 0.6606 & $\ldots$ & $\ldots$ & $\ldots$ & $\ldots$ \\
\hline $\mathrm{Fc} \times \mathrm{Yr}$ & 1 & 2.22 & 0.1433 & 0.12 & 0.7287 & 7.58 & 0.0085 & 7.59 & 0.0084 & $\ldots$ & $\ldots$ & $\ldots$ & $\ldots$ \\
\hline $\mathrm{Pt} \times \mathrm{Fc} \times \mathrm{Yr}$ & 3 & 1.32 & 0.2781 & 0.59 & 0.6243 & 2.08 & 0.1160 & 0.12 & 0.9467 & $\ldots$ & $\ldots$ & $\ldots$ & $\ldots$ \\
\hline \multicolumn{14}{|l|}{ Harvest stage } \\
\hline \multicolumn{14}{|l|}{ Main effects } \\
\hline P. thornei & 3 & 193.48 & $<0.0001$ & 174.16 & $<0.0001$ & 230.90 & $<0.0001$ & $1,244.56$ & $<0.0001$ & 265.70 & $<0.0001$ & $1,336.87$ & $<0.0001$ \\
\hline F. culmorum & 1 & 539.60 & $<0.0001$ & 713.04 & $<0.0001$ & 359.76 & $<0.0001$ & 588.30 & $<0.0001$ & 766.06 & $<0.0001$ & 21.97 & 0.0001 \\
\hline Year & 1 & 40.04 & $<0.0001$ & 25.66 & $<0.0001$ & 2.67 & 0.1078 & 178.79 & $<0.0001$ & 6.35 & 0.0144 & $\ldots$ & $\ldots$ \\
\hline \multicolumn{14}{|l|}{ Interaction } \\
\hline $\mathrm{Pt} \times \mathrm{Fc}$ & 3 & 8.97 & $<0.0001$ & 6.88 & 0.0005 & 11.38 & $<0.0001$ & 1.85 & 0.1472 & 4.71 & 0.0051 & 0.03 & 0.0323 \\
\hline $\mathrm{Pt} \times \mathrm{Yr}$ & 3 & 0.18 & 0.9073 & 4.38 & 0.0074 & 1.00 & 0.3973 & 296.97 & $<0.0001$ & 0.23 & 0.8737 & $\ldots$ & $\ldots$ \\
\hline $\mathrm{Fc} \times \mathrm{Yr}$ & 1 & 0.33 & 0.5702 & 0.29 & 0.5901 & 0.04 & 0.8443 & 336.60 & $<0.0001$ & 3.34 & 0.0725 & $\ldots$ & $\ldots$ \\
\hline $\mathrm{Pt} \times \mathrm{Fc} \times \mathrm{Yr}$ & 3 & 0.02 & 0.9968 & 0.67 & 0.5752 & 0.58 & 0.6321 & 11.91 & $<0.0001$ & 0.28 & 0.8427 & $\ldots$ & $\ldots$ \\
\hline
\end{tabular}

${ }^{\mathrm{x}}$ Data were collected prior to heading and at grain maturity during each of 2 years. Sampling consisted of four plants (replicates) during heading ( $\left.n=4\right)$ and five plants during harvest $(n=5)$.

${ }^{y} \mathrm{Rf}$ is the final nematode density $(P f)$ divided by the initial inoculum density $(P i)$.

${ }^{z}$ Source of variability. Error and total degrees of freedom (df) were 45 and 63, respectively, at heading stage and 60 and 79 , respectively, at harvest. 
plant tissue occur near the soil surface can greatly restrict the transmission of water and nutrients from entire root systems. The ultimate effect of both pathogens on maturation of wheat plants is an imposition of drought stress and nutrient unavailability on the foliage and on the maturing ears and grain $(6,8,21,28)$.

The magnitude of plant stress caused by each of these pathogens increases as plants mature. This is particularly true when plant maturation coincides with drying of the soil in regions where summer rainfall is either absent or is too low to effectively recharge the amount of moisture throughout the root zone. In this study, we found that inoculations with the highest rate of $P$. thornei and $F$. culmorum alone had approximately comparable effects on growth of winter wheat foliage. Compared with the noninoculated control at the time of harvest, these treatments resulted in reduced plant
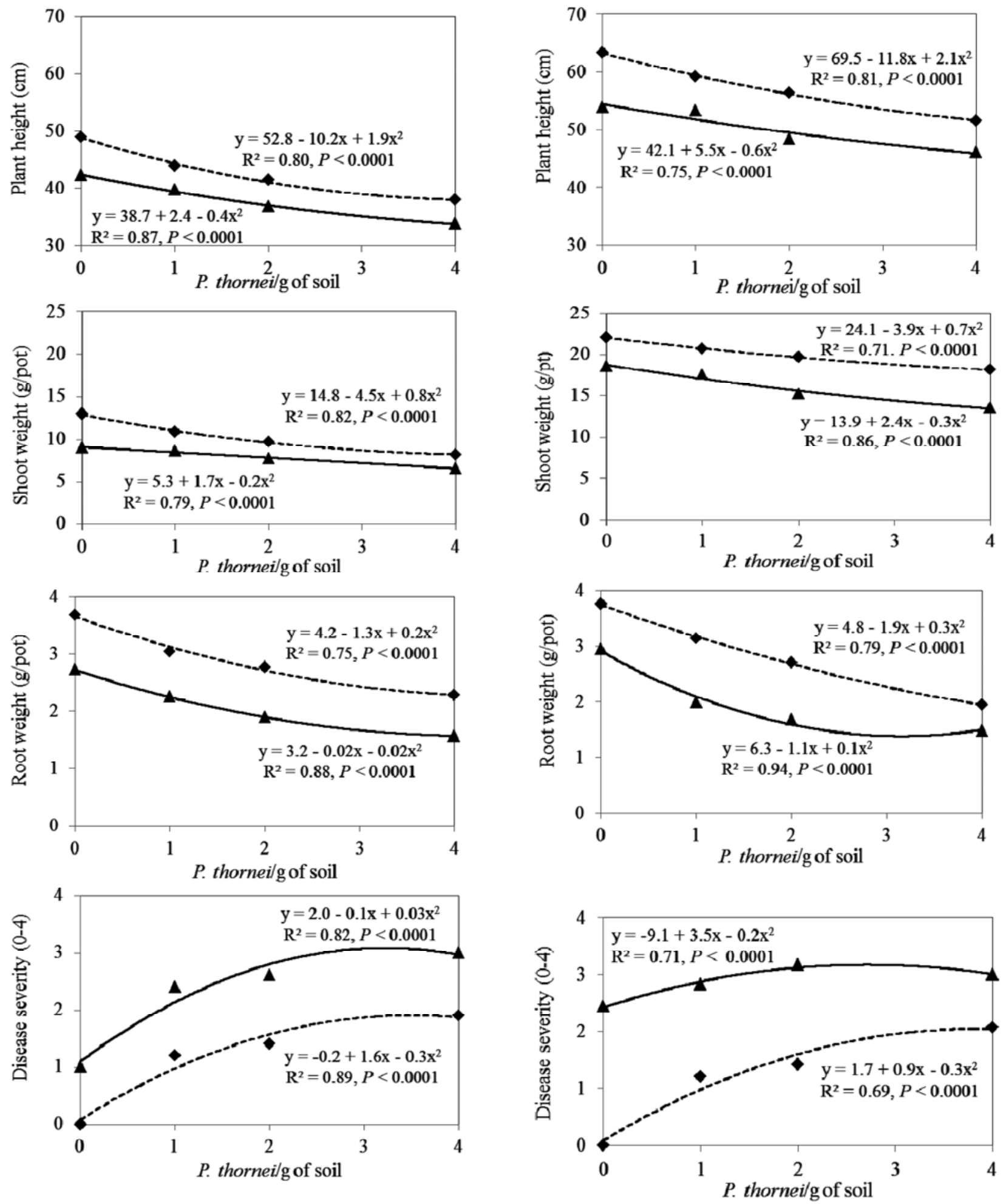

Fig. 2. Relationship between plant height (top row), shoot dry weight (second row), root dry weight (third row), and disease severity (bottom row) in rainfed winter wheat inoculated with Pratylenchus thornei (dotted line) at four levels of initial inoculum density $(0,1,2$, or 4 nematodes/g of soil) or with both Fusarium culmorum and $P$. thornei (solid line), with samples collected either before heading (left column) or at harvest (right column); datum points are means of all replicates grouped over 2 years (2010-11 and 2011-12), with $n=8$ for heading and $n=10$ for harvest. The $F$. culmorum-alone treatment is shown as the value for $\mathrm{Pt}+\mathrm{Fc}$ at the nil rate of nematode inoculation. Regressions were performed using all replicates sampled; $31 \mathrm{df}$ at heading and $39 \mathrm{df}$ at harvest. 
height of 19 and $15 \%$, respectively, and reduced shoot weight of 17 and $16 \%$, respectively. In contrast, the effect of each pathogen was of greater magnitude on root weight (48 and 22\%, respectively) and grain yield (31 and $22 \%$, respectively). Inoculation with $P$. thornei at densities commonly encountered in naturally infested fields clearly had a greater influence on root weight and grain yield than inoculation with $F$. culmorum alone. However, reduction of root weight by the combination of these treatments $(61 \%)$ was slightly less than an additive effect of the two treatments individually $(70 \%)$. In contrast, the co-inoculation effect on reduced grain yield $(63 \%)$ was slightly greater than for an additive effect for individual treatments $(53 \%)$.

Back et al. (3) described possible interactions between plantparasitic nematodes and soilborne plant-pathogenic fungi as synergistic, antagonistic, or neutral. Synergism was described as an association between the nematode and fungus that results in plant damage that exceeds the sum of individual damage by these organisms. Antagonism is the converse, in which the association results in plant damage less than that which is expected from the sum of damage by each organism. Neutral interactions occur in situations where the organisms are known to be capable of interacting but the damage caused by their association equals that caused by each of the organisms. Additive interactions occur when the organisms in the association are known not to interact with one another. Neutral and additive interactions are difficult to distinguish because the amount of damage caused by those associations of organisms is similar. Back et al. (3) also reviewed mechanisms of interactions and concluded that even low densities of fungi or nematodes can result in a disease complex of significant importance. In our study, it appears that the effects of co-inoculation by $P$. thornei and $F$. culmorum were either slightly antagonistic or neutral for foliar and root growth parameters at the time of heading and harvest. It also appears that the effect of co-inoculation was slightly synergistic with respect to grain yield. The suppression of yield by co- inoculation compared with the individual effects of these pathogens became progressively greater as the nematode inoculation rate was increased. Differences in yield suppression between co-inoculation and additive effects of individual inoculations at densities of $P$. thornei at 1, 2, or 4 nematodes/g of soil were 1,3 , and $10 \%$, respectively.

At the time of harvest during the first year of our study, the disease severity ratings indicated that $F$. culmorum alone did not cause a visually apparent disease symptom. However, that treatment was associated with significant reductions in plant height, shoot weight, root weight, and grain yield. These results suggest that the disease symptom failed to become visually apparent even though the pathogen appeared to exert a strong influence on all plant growth and yield parameters we measured. Because the fungal inoculum was placed at the soil surface, it appears possible that $F$. culmorum failed to cause the external browning symptom during the year in which rainfall was distributed across most of the growing season, except for the final 2 months. If so, the browning symptom may not be a necessary prerequisite to disruption of water and nutrient flow through adjacent conducting tissues. Hogg et al. (15) reported a significant correlation between crown rot severity scores and DNA concentrations in plant tissue during inoculated experiments in the greenhouse and in the field. However, they also reported that quantitative polymerase chain reaction was effective for assessing crown rot disease severity in mature wheat stems only if the environmental stress was sufficient to lead to development of disease symptoms. Nicholson et al. (27) also reported that visual assessment of crown rot was not always an accurate indicator of inoculum density, and that the measurement of DNA concentration provided a more accurate measure of inoculum concentration in tissue. Likewise, under naturally infected field conditions, Poole (29) and Strausbaugh et al. (44) failed to find a significant correlation between the Fusarium crown rot disease index and the DNA concentration of pathogen inoculum in the plant tissue. Likewise, Smiley
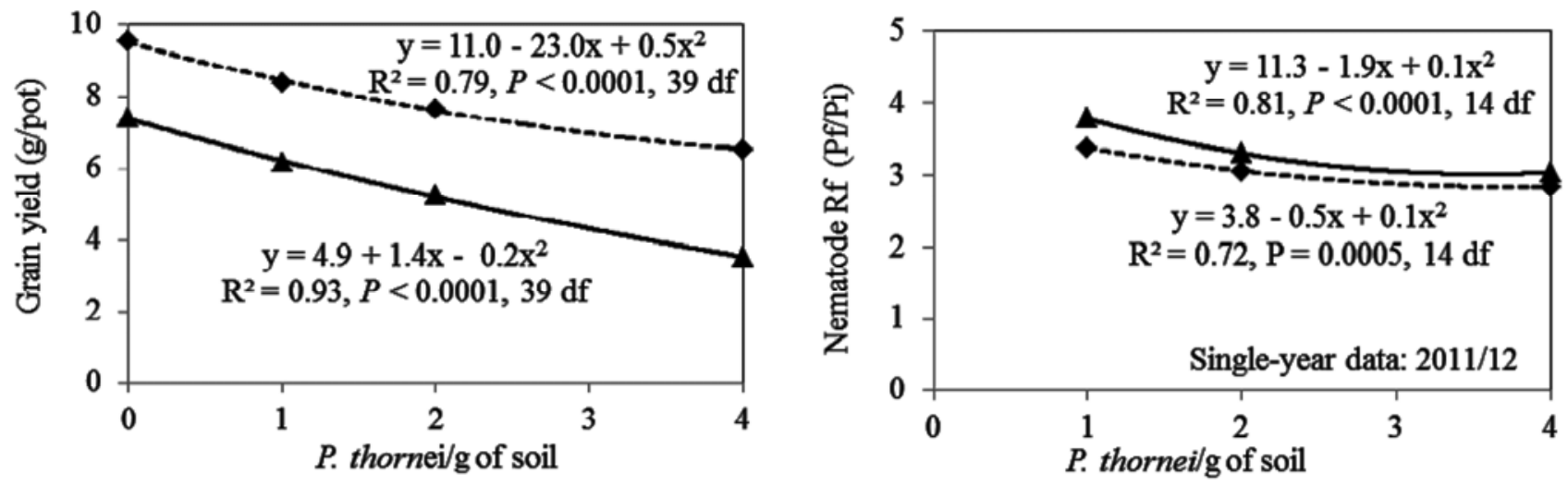

Fig. 3. Relationship between grain yield (left) and reproductive factor (Rf) for Pratylenchus thornei (right) in rainfed winter wheat inoculated with $P$. thornei (dotted line) at four levels of initial inoculum density $(0,1,2$, or 4 nematodes/g of soil) or with both Fusarium culmorum and $P$. thornei (solid line); grain yield data were grouped over 2 years (2010-11 and 2011-12) and nematode $\mathrm{Rf}$ is for 2011-12. The F. culmorum-alone treatment is shown as the value for Pt $+\mathrm{Fc}$ at the nil rate of nematode inoculation.

Table 3. Percent reduction of plant growth and grain yield parameters, averaged over two seasons, when rainfed winter wheat was grown in pots incubated under field conditions and inoculated with Pratylenchus thornei at initial densities of $0,1,2$, or 4 juveniles/g of soil (Pt0, Pt1, Pt2, and Pt4), Fusarium culmorum $(\mathrm{Fc})$ colonized millet seed at a rate of $0.65 \mathrm{~g} / \mathrm{kg}$ of soil, or co-inoculations with P. thornei and $F$. culmorum $^{2}$

\begin{tabular}{|c|c|c|c|c|c|c|c|}
\hline \multirow[b]{2}{*}{ GS, treatment } & \multicolumn{3}{|c|}{ Heading } & \multicolumn{4}{|c|}{ Harvest } \\
\hline & Plant height & Shoot weight & Root weight & Plant height & Shoot weight & Root weight & Grain yield \\
\hline Pt0 (control) & 0 & 0 & 0 & 0 & 0 & 0 & 0 \\
\hline Pt1 & 10 & 16 & 17 & 7 & 6 & 16 & 12 \\
\hline $\mathrm{Pt} 2$ & 15 & 25 & 25 & 11 & 10 & 28 & 20 \\
\hline $\mathrm{Pt} 4$ & 23 & 37 & 38 & 19 & 17 & 48 & 31 \\
\hline $\mathrm{Pt} 0+\mathrm{Fc}$ & 14 & 30 & 26 & 15 & 16 & 22 & 22 \\
\hline $\mathrm{Pt} 1+\mathrm{Fc}$ & 19 & 34 & 39 & 16 & 20 & 47 & 35 \\
\hline $\mathrm{Pt} 2+\mathrm{Fc}$ & 25 & 40 & 49 & 24 & 31 & 55 & 45 \\
\hline $\mathrm{Pt} 4+\mathrm{Fc}$ & 31 & 49 & 57 & 27 & 38 & 61 & 63 \\
\hline
\end{tabular}

${ }^{\mathrm{z}}$ Data were collected at two plant growth stages (GSs): before heading and at the time of harvest. 
et al. (41) reported that visual symptoms did not always provide an accurate assessment of crown rot damage during years where plant stress was minimal. It is likely that our finding that inoculation of plants with $F$. culmorum during a year without significant drought stress led to reductions of plant growth and yield without the appearance of typical symptoms of crown rot.

We observed no symptoms of disease in the noninoculated controls of our experiments. However, all P. thornei-only treatments caused browning of the scutellar node but not the subcrown internode or leaf sheath. This symptom does not appear to have been previously described for $P$. thornei. The symptom appeared to be associated with the inoculation of steam-pasteurized soil with $P$. thornei, because no disease symptoms were observed in the $F$. culmorum-only treatment, suggesting that cross contamination of pots or an incursion of wind-blown inoculum were not associated with this observation. Because the disease severity ratings in the $P$. thornei-only treatments continued to become greater over the interval from heading to harvest during the first but not the second year, it was possible that our observation was associated with the inoculation procedure used for these studies. The initial $P$. thornei inoculum was introduced in close proximity to the seed rather than being distributed throughout the soil in each pot. Therefore, it is likely that the inoculum density declined, at least initially, with increasing distance from the seed. A concentration of the nematode near the seed may have been responsible for the discolored scutellar nodes resulting from initial invasion of that tissue before the nematode became more uniformly distributed in soil and invaded other parts of the root system. It is also of importance, however, that disease symptoms from each of the pathogens in this study did not exceed the midpoint of our disease severity rating scale. Therefore, we concluded that inoculation densities for both pathogens were appropriate for distinguishing effects of the pathogens individually and when co-inoculated into soil. In short, the inoculum densities used in this study were neither too low to observe effects on plant growth nor so high that they generated overpowering effects that could mask the interactions among pathogens. This is also suggested by the maximum reductions in grain yields observed in this trial: $31 \%$ by $P$. thornei and $22 \%$ by F. culmorum. Under naturally infested field conditions at other locations, yield reductions from each pathogen alone have often far exceeded the values measured in this study $(39,43)$.

We conclude that the combined effects of P. thornei and F. culmorum are mostly additive rather than antagonistic or synergistic. However, the presence of both pathogens suppressed yield of winter wheat by a slightly greater magnitude than the additive effects of the individual pathogens, suggesting a synergistic effect on yield. Grain yield from the combined effects of these pathogens under rainfed conditions was suppressed as much as $63 \%$ over the 2 years of this study. Management practices for winter wheat should clearly become more holistically focused to include all potential pathogens rather than primarily the density of plant-parasitic nematodes or root- and crown-invading soil-borne plant pathogenic fungi.

\section{Literature Cited}

1. Abawi, G. S., and Chen, J. 1998. Concomitant pathogen and pest interactions. Pages 135-158 in: Plant and Nematode Interactions. K. R. Barker, G. A. Pederson, and G. L. Windham, eds. American Society of Agronomy, Madison, WI.

2. Atkinson, G. F. 1892. Some diseases of cotton. Ala. Polytech. Inst. Agric. Exp. Stn. Bull. 41:61-65.

3. Back, M. A., Haydock, P. P. J., and Jenkinson, P. 2002. Disease complexes involving plant parasitic nematodes and soilborne pathogens. Plant Pathol. 51:683-697.

4. Bell, N. L., and Watson, R. N. 2001. Optimising the Whitehead and Hemming tray method to extract plant parasitic and other nematodes from two soils under pasture. Nematology 3:179-185.

5. Benedict, W. G., and Mountain, W. B. 1956. Studies on the etiology of a root rot of winter wheat in Southern Ontario. Can. J. Bot. 34:159-174.

6. Burgess, L. W., Backhouse, D., Summerell, B. A., and Swan, L. J. 2001. Crown rot of wheat. Pages 271-294 in: Fusarium. B. A. Summerell, J. F. Leslie, D. Backhouse, W. L. Bryden, and L. W. Burgess, eds. American Phytopathological Society, St. Paul, MN.
7. Castillo, P., and Vovlas, N. 2007. Pratylenchus (Nematoda: Pratylenchidae): Diagnosis, Biology, Pathogenicity and Management. Nematol. Monogr. Perspect. Vol 6. Brill Academic Publishers, Leiden, The Netherlands.

8. Chekali, S., Gargouri, S., Paulitz, T., Nicol, J. M., Rezgui, M., and Nasraoui, B. 2011. Effects of Fusarium culmorum and water stress on durum wheat in Tunisia. Crop Prot. 30:718-725.

9. Coolen, W. A., and D'Herde, C. J. 1972. Method for the Quantitative Extraction of Nematodes from Plant Tissue. State Nematology and Entomology Research Station, Ghent, Belgium.

10. Evans, K., and Haydock, P. P. J. 1993. Interactions of nematodes with rootrot fungi. Pages 104-133 in: Nematode Interactions. M. Wajid Khan, ed. Chapman and Hall, London.

11. Hajieghrari, B. 2009. Wheat crown and root rotting fungi in Morgan area, northwest of Iran. Afr. J. Biotechnol. 8:6214-6219.

12. Hajihasani, M., Hajihassani, A., and Khaghani, S. 2012. Incidence and distribution of seed-borne fungi associated with wheat in Markazi Province, Iran. Afr. J. Biotechnol. 11:6290-6295.

13. Hajihassani, A., Tanha Maafi, Z., Ahmadi, A. R., and Taji, M. 2011. Survey and biology of cereal cyst nematode, Heterodera latipons, in rain-fed wheat in Marakzi province, Iran. Int. J. Agric. Biol. 13:576-580.

14. Heidarian, A., and Ershad, J. 2001. Identification of fungi associated with foot and root of winter wheat in the Chaharmahal-va-Bakhtiari province. Iran. J. Plant Pathol. 37:29-33.

15. Hogg, A. C., Johnson, R. H., and Dyer, A. T. 2007. Applying real-time quantitative PCR to Fusarium crown rot of wheat. Plant Dis. 91:1021-1028.

16. Kazemi, H. 2002. Fusarium species associated with root and crown rot of wheat in Tehran province. Page 22 in: Proc. 15th Iran. Plant Prot. Congr. Vol. 2: Plant Diseases and Weeds. Razi University, Kermanshah, Iran.

17. Kheiri, A. 1972. Plant parasitic nematodes (Tylenchida) from Iran. Biolog Jaarboek Dodon. 40:224-239.

18. Loof, P. A. A. 1991. The family Pratylenchidae Thorne, 1949. Pages $363-$ 423 in: Manual of Agricultural Nematology. W. R. Nickle, ed. Marcel-Dekker, New York.

19. Mansoori, B., and Pazhomand, M. A. 2005. Field reaction of some wheat advanced lines and cultivars to common root and crown rot pathogens in Fars province. Seed Plant 21:81-91.

20. Mansori, B., Ravanlou, A., Norolahi, K.H., Azadbakht, N., Jafari, A., and Ghalandar, M. 2002. Common root and crown rot diseases of wheat in West Azarbayejan, Illam, Lorestan, Zanjan and Markazi provinces. Page 41 in: Proc. 15th Iran. Plant Prot. Congr. Vol. 2: Plant Diseases and Weeds. Razi University, Kermanshah, Iran.

21. Marley, J. M., and Littler, J. W. 1989. Winter cereal production on the Darling Downs-an 11 year study of fallowing practices. Aust. J. Exp. Agric. 29:807-827.

22. McGawley, E. C., and Overstreet, C. 1998. Rice and other cereals. Pages 455-486 in: Plant and Nematode Interactions. K. R. Barker, G. A. Pederson, and G. L. Windham, eds. American Society of Agronomy, Madison, WI

23. Meagher, J. W., Brown R. H., and Rovira, A. D. 1978. The effects of cereal cyst nematode (Heterodera avenae) and Rhizoctonia solani on the growth and yield of wheat. Aust. J. Agric. Res. 29:1127-1137.

24. Meagher, J. W., and Chambers, S. C. 1971. Pathogenic effects of Het erodera avenae and Rhizoctonia solani and their interaction on wheat. Aust. J. Agric. Res. 22:189-194.

25. Moody, E. H. 1973. Culture of the root-lesion nematode Pratylenchus vulnus on carrot disks. J. Nematol. 5:225-226.

26. Nelson, P. E., Toussoun, T. A., and Marasas, W. F. O. 1983. Fusarium Species: An illustrated Manual for Identification. The Pennsylvania State University Press, University Park.

27. Nicholson, P., Simpson, D. R., Weston, G., Rezanoor, H. N., Lees, A. K, Parry, D. W., and Joyce, D. 1998. Detection and quantification of Fusarium culmorum and Fusarium graminearum in cereals using PCR assays. Physiol. Mol. Plant Pathol. 53:17-38.

28. Papendick, R. I., and Cook, R. J. 1974. Plant water stress and development of Fusarium foot rot in wheat subjected to different cultural practices. Phytopathology 64:358-363.

29. Poole, G. J. 2010. Identification of quantitative trait loci (QTL) for resistance to Fusarium crown rot in wheat and a survey of Fusarium pseudograminearum and F. culmorum in the Pacific Northwest of the U.S. Ph.D. dissertation, Washington State University, Pullman. Online publication. http://www.dissertations.wsu.edu/Dissertations/Spring2010/g_poole 042910.pdf

30. Poole, G. J., Smiley, R. W., Paulitz, T. C., Walker, C. A., Carter, A. H., See, D. R., and Garland-Campbell, K. 2012. Identification of quantitative trait loci (QTL) for resistance to Fusarium crown rot (Fusarium pseudograminearum) in multiple assay environments in the Pacific Northwestern US. Theor. Appl. Genet. 125:91-107.

31. Poormansouri, T., Jafari, H., Arjmandian, A., Frootan, A., Yonesi, H., Smaeelzade, S. A., and Ghalandar, M. 2007. Study on root and crown rot pathogenic soil borne fungi of barley in different provinces. Iran. Res. Inst. Plant Prot. Rep. No. 24572. Tehran, Iran.

32. Powell, N. T. 1971. Interactions between nematodes and fungi in disease complexes. Annu. Rev. Phytopathol. 9:253-274.

33. Ravanlou, A., and Banihashemi, Z. 1999. Taxonomy and pathogenicity of Fusarium spp. associated with root and crown rot of wheat in Fars. Iran. J. 
Plant Pathol. 35:12-14.

34. Riedel, R. M. 1988. Interactions of plant-parasitic nematodes with soilborne plant pathogens. Agric. Ecosyst. Environ. 24:281-292.

35. Rivoal, R., and Cook, R. 1993. Nematode pests of cereals. Pages 259-303 in: Plant Parasitic Nematodes in Temperate Agriculture. K. Evans, D. L. Trudgill, and J. M. Webster, eds. CAB International, Wallingford, UK.

36. Saremi, H., Ammareliou, A., and Jafary, H. 2007. Incidence of crown rot disease of wheat caused by Fusarium pseudograminearum as a new soil born fungal species in north west Iran. Pak. J. Biol. Sci. 10:3606-3612.

37. Scholz, U. 2001. Biology, pathogenicity and control of the cereal cyst nematode Heterodera latipons Franklin, on wheat and barley under semiarid conditions, and interactions with common root rot Bipolaris sorokiniana Shoemaker. Ph.D. thesis, University of Bonn, Germany.

38. Simpfendorfer, S., McMullen, G., and Brill, R. 2012. Interaction of crown rot with root-lesion nematodes. Page 34 in: Proc. 1st Int. Crown Rot Workshop for Wheat Improvement. R. I. S. Brettell and J. M. Nicol, eds. Narrabri, NSW, Australia.

39. Smiley, R. W., Backhouse, D., Lucas, P., and Paulitz, T. C. 2009. Diseases which challenge global wheat production: root, crown, and culm rots. Pages 125-153 in: Wheat Science and Trade. B. F. Carver, ed. Wiley-Blackwell, Ames, IA.

40. Smiley, R. W., Gourlie, J. A., Easley, S. A., and Patterson, L. M. 2005. Pathogenicity of fungi associated with the wheat crown rot complex in Oregon and Washington. Plant Dis. 89:949-957.

41. Smiley, R. W., Gourlie, J. A., Easley, S. A., Patterson, L.-M., and Whittaker, R. G. 2005. Crop damage estimates for crown rot of wheat and barley in the Pacific Northwest. Plant Dis. 89:595-604.

42. Smiley, R. W., and Machado, S. 2009. Pratylenchus neglectus reduces yield of winter wheat in dryland cropping systems. Plant Dis. 93:263-271.

43. Smiley, R. W., and Nicol, J. M. 2009. Nematodes which challenge global wheat production. Pages 171-187 in: Wheat Science and Trade. B. F. Carver, ed. Wiley-Blackwell, Ames, IA.

44. Strausbaugh, C. A., Overturf, K., and Koehn, A. C. 2005. Pathogenicity and real-time PCR detection of Fusarium spp. in wheat and barley roots. Can. J.
Plant Pathol. 27:430-438

45. Taheri, A., Hollamby, G. J., Vanstone, V. A., and Neate, S. M. 1994. Interaction between root-lesion nematode, Pratylenchus neglectus (Rensch 1924) Chitwood and Oteifa 1952, and root rotting fungi of wheat. N.Z. J. Crop Hortic. Sci. 22:181-185.

46. Tanha Maafi, Z. 2005. Study on parasitic nematodes fauna of cereal in Iran. Final report of research project submitted to Agricultural Scientific Information and Documentation Centre, Iran. Online publication. http://agris.fao. org/agris-search/search/display.do?f=2008\%2FIR\%2FIR0805.xml\%3BIR 2007000564

47. Tanha Maafi, Z., Nicol, J. M., Kazemi, H., Ebrahimi, N., Gitty, M., Ghalandar, M., Mohammedi-Pour, M., and Khoshkhabar, Z. 2009. Cereal cyst nematodes, root rot pathogens and root lesion nematodes affecting cereal production in Iran. Pages 51-55 in: Cereal Cyst Nematodes: Status, Research and Outlook. I. T. Riley, J. M. Nicol, and A. A. Dababat, eds. CIMMYT, Ankara, Turkey.

48. Tanha Maafi, Z., Sturhan, D., Kheiri, A., and Geraert, E. 2007. Species of the Heterodera avenae group (Nematoda: Heteroderidae) from Iran. Russ. J. Nematol. 15:49-58.

49. Taylor, C. E. 1990. Nematode interactions with other pathogens. Ann. Appl. Biol. 116:405-416.

50. Thompson, J. P., Mackenzie, J., and Amos, R. 1995. Root-lesion nematode (Pratylenchus thornei) limits response of wheat but not barley to stored soil moisture in the Hermitage long-term tillage experiment. Aust. J. Exp. Agric. 35:1049-1055.

51. Thompson, J. P., Mackenzie, J., and Sheedy, G. H. 2012. Root-lesion nematode (Pratylenchus thornei) reduces nutrient response, biomass and yield of wheat in sorghum-fallow-wheat cropping systems in a subtropical environment. Field Crops Res. 137:126-140.

52. Wajid Khan, M. 1993. Mechanisms of interactions between nematodes and other plant pathogens. Pages 53-78 in: Nematode Interactions. M. Wajid Khan, ed. Chapman and Hall, London.

53. Zare, R., and Ershad, D. 1997. Fusarium species isolated from cereals in Gorgan area. Iran. J. Plant Pathol. 33:1-14. 